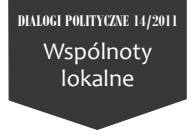

ANNA POKORSKA

Instytut Socjologii UMK

\title{
Rola samorządów lokalnych w rozwoju obszarów wiejskich
}

$\mathrm{O}$

bszary wiejskie Polski cieszą się w ostatnich latach wzrastającą uwagą. Ich problemom, pożądanym kierunkom rozwoju, perspektywom i zagrożeniom poświęca się wiele debat, artykułów, analiz. Duża w tym zasługa Unii Europejskiej, która rozwój rustykalnych terenów Europy wspomaga nie tylko odpowiednimi zarządzeniami i dyrektywami, ale także hojnym finansowym wsparciem. Zainteresowanie przyszłością i stanem obszarów wiejskich w Polsce jest podyktowane również tym, iż zgodnie z metodologią ich wyodrębniania przez Główny Urząd Statystyczny, opartą na podziale administracyjnym, zajmują one ponad 93\% powierzchni kraju i są zamieszkiwane przez około 38,8\% ogółu ludności (stan na 2007 rok) ${ }^{1}$. Choć dane te same w sobie uzasadniają potrzebę diagnozowania kondycji polskiej wsi i kreślenia wizji jej przyszłości, to jednak warto zwrócić uwagę również na inne elementy charakterystyki.

Co istotne dla zrozumienia obecnego położenia mieszkańców obszarów wiejskich w Polsce, to fakt, iż od 2002 roku spada systematycznie liczba osób zatrudnionych w rolnictwie. Jednocześnie dochody z pracy poza rolnictwem stanowią dopiero drugie w kolejności źródło utrzymania wiejskich gospodarstw domowych, podczas gdy pierwszym i podstawo-

Zarys kierunków rozwoju obszarów wiejskich, Dokument Ministerstwa Rolnictwa i Rozwoju Wsi opracowany przez Departament Rozwoju Obszarów Wiejskich i Departament Programowania i Analiz, Warszawa 2009, s. 3. 
wym są emerytury, renty i zasiłki ${ }^{2}$. Według badaczy oznacza to, że polska wieś wymaga ,przebudowy” opartej na „równoległym dążeniu do unowocześniania rolnictwa i gospodarki żywnościowej oraz rozwijaniu przedsiębiorczości poza rolnictwem" ". Zmiana struktury zawodowej mieszkańców wsi, choć stanowi element podstawowy i konieczny, nie jest jednak warunkiem wystarczającym jej harmonijnego rozwoju. Podejmowane w tym kierunku działania powinny obejmować również inne aspekty, które w dokumentach Ministerstwa Rolnictwa i Rozwoju Wsi opisywane są w następujący sposób: „Obszary wiejskie powinny stać się atrakcyjnym miejscem pracy, zamieszkania, wypoczynku i prowadzenia działalności rolniczej lub pozarolniczej, z zachowaniem unikalnych walorów przyrodniczych, krajobrazowych i kulturowych tych terenów dla przyszłych pokoleń. [...] Mieszkańcy obszarów wiejskich powinni uzyskać szeroki dostęp do edukacji, zatrudnienia, służby zdrowia, dóbr kultury i nauki, narzędzi społeczeństwa informacyjnego i niezbędnej infrastruktury technicznej w odpowiednim standardzie". . Powyższe postulaty i zalecenia kondensują się w haśle: „Zrównoważony rozwój, wielofunkcyjność i konkurencyjność obszarów wiejskich", które w różnych formach przejawia się w rządowych, naukowych i publicystycznych analizach wyzwań stojących przed polską wsią. Hasło to jest wyrazem przekonania, że współczesne obszary wiejskie to nie tylko produkcja żywności, ale również dobra publiczne, istotne dla dobrobytu i dobrostanu całego społeczeństwa, do których zalicza się: zasoby przyrodnicze, w tym bioróżnorodność, bogactwo regionalnych odmian kultury ludowej i społeczny kapitał lokalnych społeczności. Wspomniane hasło oznacza również wyrównywanie dostępu mieszkańców obszarów wiejskich do dóbr i usług publicznych, wśród których szczególne miejsce zajmuje edukacja. Upatruje się w niej klucza do poprawy mobilności zawodowej oraz do budowy na wsi otwartego na dyskusję, świadomego i kreatywnego społeczeństwa obywatelskiego.

\section{Rozwój jako proces endogenny}

Wszystkie wyżej zarysowane w skrócie założenia i kierunki wyznaczające trajektorię rozwoju obszarów wiejskich wskazują, iż sukces wszelkich strategii w tym względzie jest wypadkową wielu czynników, a zre-

Tamże, s. 4.

Tamże, s. 7.

Tamże. 
alizowanie ambitnych planów dotyczących przekształceń wsi wymaga synergicznego działania różnych podmiotów.

Choć celów rozwoju jest wiele (od ekonomicznych do społecznych) to duża część komentatorów zgadza się, co do zasadniczego sposobu ich realizacji. Podkreśla się, że istotne jest aby, odbywał się w sposób endogenny, angażując wewnętrzne zasoby (ludzkie, kulturowe, gospodarcze) danej społeczności, pozwalając jej członkom na aktywne uczestnictwo, czyli decydowanie o celach i podejmowanych sposobach działania. Współczesne definicje rozwoju $\mathrm{w}$ dużym stopniu wiążą ten termin $\mathrm{z}$ budową społeczeństwa obywatelskiego. Stąd też jako realizatorów, menadżerów i inicjatorów rozwoju obszarów wiejskich coraz częściej wymienia się organizacje non-profit, rozmaite fundacje, stowarzyszenia, koła zainteresowań, czyli organizacje, którym intuicyjnie przypisuje się podejście oddolne, pracę metodą społecznych konsultacji i osadzania rozwiązań problemów w lokalnej tradycji.

Tylko część osób zaangażowana w tematykę rozwoju obszarów wiejskich ku aktywnym, przedsiębiorczym, wyedukowanym i ekonomicznie stabilnym społecznościom lokalnym podkreśla, że kołem zamachowym tego procesu jest „dobre przygotowanie na różnych szczeblach kompetentnych urzędników administracji i liderów życia społeczno-gospodarczego, zwłaszcza takich, którzy:

- rozumieją, na czym polega rozwój obszarów wiejskich,

- potrafią opracować strategię rozwoju i programy oraz projekty, które złożą się na realizację wspomnianych strategii,

- będą umieli znaleźć środki finansowe na wsparcie przygotowanych programów,

- przekonają ludność lokalną do angażowania się w realizację programów"

Uważa się, że samorządy terytorialne są niewydolne, bo źle zorganizowane i działające $\mathrm{w}$ oderwaniu od potrzeb obywatela. Znawcy problematyki podkreślają, że w zamyśle reformatorów z 1998 roku „Samorząd lokalny miał być z założenia przekazaniem większej władzy „na dół”, na rzecz obywatela, jednak lokalna ludność niewiele z tej reformy w tej materii uzyskała. Częstokroć układy partyjne i zobowiązania osobiste są

5 E. Makowska, Wielofunkcyjny rozwój obszarów wiejskich - wsparcie lokalnych inicjatyw, Regionalne Centrum Doradztwa Rozwoju Rolnictwa i Obszarów Wiejskich we Wrocławiu, 2002 [http://www.ppr.pl/artykul-wielofunkcyjny-rozwoj-obszarow-wiejskich-nbsp2897-dzial-19.php; dostęp: 04.08.2010]. 
radnym bliższe niż interesy ich wyborców". Tymczasem, na podstawie dostępnych materiałów i badań, stawiam tezę, że samorządy terytorialne, pomimo trapiących je słabości, odgrywają i będą odgrywać w Polsce istotną rolę w rozwoju obszarów wiejskich.

W świetle prezentowanych $\mathrm{w}$ artykule danych, nowego znaczenia nabierają tezy, takich badaczy, jak Ryszard Szarfenberg, który twierdzi, że mamy do czynienia z idealizacją trzeciego sektora, poprzez przypisywanie tylko organizacjom obywatelskim przymiotów działalności z pobudek altruistycznych i prospołecznych, podczas gdy pozostałe sektory mają być zdominowane przez interesy własne polityków, urzędników, przedsiębiorców i pracowników oraz reprezentujących ich organizacji, czyli partii politycznych, korporacji zawodowych, organizacji przedsiębiorców i związków zawodowych ${ }^{7}$. Tymczasem organizacje non-profit nie są jedyną odpowiedzią na trudności, choć oczywiście przyczyniają się do poprawy sytuacji na obszarach wiejskich. Pomimo słabości (upartyjnienie, niegospodarność, niesamodzielność) kluczową rolę wciąż odgrywa samorząd, zwłaszcza, że współczesne rozwiązania prawne pozwalają mu na podejmowanie szeroko zakrojonych działań na rzecz zrównoważonego, wielokierunkowego rozwoju i budowania dojrzałego społeczeństwa obywatelskiego, będącego gwarantem efektywnych urzędów.

\section{„Partia kieruje a rząd rządzi”" vs „tyle państwa, na ile, to konieczne, tyle społeczeństwa, na ile to możliwe"}

Pierwsze z zacytowanych haseł, dzisiaj na szczęście, nie jest już wiernym odbiciem rzeczywistości. Reforma administracji wyrugowała, charakterystyczną dla ustroju komunistycznego, skrajną centralizację na poziomie administracji terytorialnej, której struktura stanowiła, że: „rady gminne były podporządkowane radom wojewódzkim, a te z kolei Radzie Państwa. Naczelnicy gmin byli podporządkowani radom, ale jednocześnie byli podwładnymi wojewodów, a ci podlegali odpowiedniemu ministro-

Z referatu Edwarda Gierka, VIII Plenum KC PZPR, 7 II 1971 r.

P. Witkowski, Alternatywne modele samorzadu terytorialnego, [w:] Samorząd terytorialny w Europie i Polsce. Wybrane aspekty, red. K. Kociubiński, Toruń 2008, s. 89.

R. Szarfenberg, Słabości trzeciego sektora i partnerstwa publiczno-prywatnego, „Trzeci sektor”, 2006, nr 4, s. 119. 
wi”, Efektem tej zbiurokratyzowanej struktury był „brak własnej inicjatywy, zwłaszcza, że gminy nie miały osobowości prawnej i zarządzały jedynie własnością państwową $\mathrm{w}$ granicach nadanych im pełnomocnictw, a finanse lokalne stanowiły część budżetu, uchwalonego przez Sejm"”.

Obecne zasady samorządu terytorialnego określa, ratyfikowana przez Polskę, Europejska Karta Samorządu Lokalnego. Wedle jej zapisów: „samorząd terytorialny oznacza prawo i zdolność społeczności lokalnej, w granicach określonych prawem, do kierowania i zarządzania zasadniczą częścią spraw publicznych na ich własną odpowiedzialność i w interesie ich mieszkańców" ${ }^{\prime 10}$. Równie wyraźnie prawa i obowiązki samorządu określa Konstytucja RP, której art. 15 ust. 1 stwierdza: „Ustrój terytorialny Rzeczpospolitej Polskiej zapewnia decentralizację władzy publicznej”,11, a art. 16 ust 2. głosi: „Samorząd terytorialny uczestniczy w sprawowaniu władzy publicznej. Przysługującą mu w ramach ustaw istotną część zadań publicznych samorząd wykonuje w imieniu własnym i na własną odpowiedzialność"12.

Osią tych postanowień jest zasada subsydiarności, która stwarza doskonały klimat dla rozwoju samorządu jako centralnego podmiotu budowy społeczeństwa obywatelskiego. Według charakterystyki Jerzego Regulskiego, zasada pomocniczości, przyjmuje człowieka za podstawowy podmiot wszelkich spraw i głosi, że ,inne instytucje powinny być tworzone jedynie jako pomocnicze w stosunku do działań i potrzeb poszczególnej osoby. Zatem gmina ma się zajmować tym, czego pojedynczy człowiek, wraz z rodziną, nie może wykonać. Powiat powinien być traktowany jako pomocniczy w stosunku do gminy, a województwo - w stosunku do powiatu [...] Mamy tu do czynienia z niejako odwróconą hierarchią. Instytucje są nadbudowywane tam, gdzie organizacje mniejsze, położone bliżej obywatela, nie są w stanie realizować bardziej złożonych zadań, a zatem [...] zgodnie z zasadą pomocniczości rola starosty jest pomocnicza w sto-

8 J. Regulski, Samorząd terytorialny [http://www.frdl.org.pl/downloads/poradnik radnego_06/ rozdzial_I.pdf; dostęp: 05.08.2010].

Tamże, s. 20.

10 Europejska Karta Samorządu Lokalnego z dn. 15.10.1985, art. 3 pkt 1, zob. Dz. U. z 1994 nr 124, poz. 607 [http://isap.sejm.gov.pl/DetailsServlet?id=WDU19941240607; dostęp: 14.08.2010].

11 Konstytucja Rzeczypospolitej Polskiej z dn. 02.04.1997 r. [http://www.sejm.gov.pl/prawo/ konst/polski/ kon1.htm; dostęp: 14.08.2010].

12 Tamże. 
sunku do zadań wójta, a urzędnik centrum ma wspomagać samorządy i zajmować się jedynie tym, czym one nie mogą"13.

Sytuacja prawna samorządów terytorialnych zmieniła się zatem diametralnie. Z jednostek podporządkowanych, stały się instytucjami samodzielnymi i zgodnie ze swoją nazwą samorządnymi, czyli władnymi do rozwiązywania własnych, lokalnych spraw na własną odpowiedzialność. Dziedzictwo komunizmu wciąż jednak wpływa na postrzeganie miejsca lokalnej samorządności w życiu wspólnoty, skutkując niedocenianiem ich efektywności i rzeczywistych możliwości codziennego służenia potrzebom swych obywateli. Przyczyn tego stanu rzeczy jest oczywiście więcej, ale biorąc pod uwagę, iż ich analiza nie jest celem tego artykułu, skupię się na opisie tych aspektów działania samorządów, które zmieniają obraz sytuacji.

\section{Oddziaływanie samorządu lokalnego i jego jednostek pomocniczych na rozwój lokalny}

Ramy prawne samorządów terytorialnych, jak i zalecania zasady subsydiarności, sprawiają, że samorządy lokalne, przynajmniej w teorii, mogą z powodzeniem wykonywać swoją funkcję stymulatora lokalnego rozwoju, nie ingerując w zasadę jego oddolności i wykorzystywania zasobów tkwiących w społeczności lokalnej. Potwierdzają to liczne przykłady. Jednym z najbardziej wymownych są losy podejścia typu LEADER, wywodzącego się z koncepcji community development, a implementowanego przez kraje Unii Europejskiej w odpowiedzi na szereg negatywnych zjawisk charakterystycznych dla obszarów wiejskich (starzenie się populacji wiejskiej, obniżanie się subiektywnie postrzeganej jakości życia, brak aktywności społecznej, niszczenie zasobów naturalnych), powodujących głęboki kryzys demograficzny, gospodarczy i kulturowy. Program LEADER na gruncie polskim, jak pisze, we wstępie do opracowania poświęconego doświadczeniom związanym z jego wdrażaniem i realizacją, Krzysztof Wasielewski, „okazał się inicjatywą ważną, która ma ambicje rozwiązywania problemów obszarów wiejskich w sposób i na skalę do tej pory niespotykaną" ${ }^{14}$. Jest to zasługa nowatorskiego założenia, że praca na rzecz rozwo-

3 J. Regulski, Samorząd terytorialny [http://www.frdl.org.pl/downloads/poradnik_ radnego_06/rozdzial_I.pdf; dostęp: 05.08.2010].

${ }^{14}$ K. Wasielewski, Wprowadzenie, [w:] Tworzenie partnerstw lokalnych i ich sieci na obszarach wiejskich. Doświadczenia z funkcjonowania programu LEADER w Polsce w latach 2004-2009, red. K. Wasielewski, Bydgoszcz 2009, s. 10. 
ju obszarów wiejskich powinna opierać się kooperacji urzeczywistnianej przez lokalne publiczno-prywatne partnerstwa w postaci Lokalnych Grup Działania, które strategię rozwoju dla danego obszaru wypracują i wprowadzą w sposób oddolny poprzez zintegrowane i wielosektorowe działania. Punkt ciężkości w podejściu LEADER znajduje się zatem w tworzeniu partnerstw i łączeniu sił oficjalnej administracji z działaniami oddolnymi (osób prywatnych lub organizacji pozarządowych).

Znamienny jest jednak fakt, że implementacja LEADERA nie byłaby możliwa, gdyby nie gotowość urzędników do jego propagowania. Na etapie powstawania Lokalnych Grup Działania, niezbędnego wsparcia organizacyjnego, doradczego i finansowego, najczęściej udzielał samorząd terytorialny. Jacek Kukowski pisze: „Analiza liczby wniosków złożonych przez sektor publiczny w Schemacie I pozwala stwierdzić, iż kompetencje i aktywność lokalnych samorządów były ważnym czynnikiem prowadzącym do aktywizowania lokalnych społeczności wiejskich i ich udziału w Pilotażowym Programie LEADER+" ${ }^{15}$.

Potencjał samorządu lokalnego jako sprawczej siły pozytywnych inicjatyw, potwierdzają też badania empiryczne nad wizerunkiem władzy. Wynika z nich, że samorząd lokalny i jego przedstawiciele są generalnie lepiej oceniani niż instytucje tzw. wielkiej polityki ${ }^{16}$. Co prawda, według danych CBOS, ponad połowa badanych $(56,4 \%)$ wskazuje, że władze lokalne cieszą się z ich strony małym zaufaniem, a w ogóle nie ma do nich zaufania niemal jedna piąta badanych (18\%), to jednak więcej niż jedna piąta respondentów obdarza przedstawicieli samorządu lokalnego dużym zaufaniem, a czterech na stu, ma do nich pełne zaufanie $(4,2 \%)^{17}$. Przywołane wyniki socjolog Katrzyna Dwojna komentuje słowami: „To, że jedna czwarta badanych wierzy w intencje władztwa lokalnego, można traktować jako emblemat powolnego wrastania samorządu terytorialnego w społeczności oraz jego funkcjonalności, co moglibyśmy uznać za wynik pozwalający na optymizm"18.

15 J. Kukowski, Szanse i zagrożenia związane z programem LEADER - z perspektywy samorządu województwa, [w:] Tworzenie partnerstw lokalnych $i$ ich sieci na obszarach wiejskich. Doświadczenia z funkcjonowania programu LEADER w Polsce $w$ latach 2004-2009, red. K. Wasielewski, Bydgoszcz 2009, s. 95.

${ }^{16}$ K. Dojwa, Samorzad lokalny jako kreator spoleczeństwa obywatelskiego w Polsce. Wybrane aspekty, [w:] Samorząd pomocniczy jako czynnik pobudzający społeczeństwo obywatelskie na wsi, red. A. Sakson, P. Węgierkiewicz, Konin 2010, s. 107.

17 Zaufanie społeczne w latach 2002-2008, CBOS, 2008.

18 K. Dojwa, Samorzą lokalny jako kreator..., s. 106. 
W tym kontekście warto również zwrócić uwagę na rolę tzw. samorządności bazowej, czyli najniższego szczebla władzy gminnej, rozumianej w warunkach obszarów wiejskich przez aktywność sołtysa. Sołectwa w Polsce, z jednej strony, uważane są za ważną instytucję, a z drugiej, część badaczy przypisuje im bardzo drugorzędne funkcje lub zupełnie pozbawia znamion funkcjonalności, opisując ich bierność i apatię ${ }^{19}$. Piotr Matczak pisze „Zakres działań podejmowanych przez sołectwa jest zwykle niewielki i często sprowadza się do tego, że sołtys zbiera podatek oraz interweniuje w gminie w sprawach dróg czy oświetlenia" $^{20}$. Z drugiej jednak strony broni hipotezy, że trwałość sołectwa nie jest przypadkiem, a ,jego funkcjonalność istnieje, choć jest ukryta i inna niż należałoby oczekiwać” ${ }^{21}$. Zdaniem badacza „sołtys i sołectwo stanowią dla poszczególnych wsi rodzaj struktury bezpieczeństwa [...] sołtys służy temu, by dbać o interesy wsi, a w szczególności, by zapobiegać dyskryminacji wynikającej z nieobecności przy podejmowaniu ważnych decyzji" "22. Zdaniem autora jest to wyjaśnienie słabego działania sołectw, ale jednocześnie ich trwałości. Funkcjonują jako „polisa ubezpieczeniowa”, „są podtrzymywane po to, by wspólnota miała kanał protestu i działania, gdy jej interesy są zignorowane. Sołtys ma lobować w interesach wsi, pilnować jej interesów i znaleźć odpowiednie ulokowanie w sieciach przepływu informacji" ${ }^{\prime 23}$. Według badań ta funkcja sołectw nie jest fasadowa, a sołtys jest wciąż najczęstszym źródłem wiadomości na temat lokalnych spraw, a zarazem pośrednikiem pomiędzy mieszkańcami a radnymi czy wójtem lub burmistrzem ${ }^{24}$. Z reprezentatywnych, ogólnopolskich badań opinii mieszkańców gmin wiejskich na temat sołtysa, w ramach projektu Samorzą pomocniczy jako czynnik pobudzajacy społeczeństwo obywatelskie na wsi, wynika, że sołtys jest bardzo rozpo-

19 Por. M. Derek, A. Mielczarek, Polish Solectwo - A Latent Fidel for Rural Governance, [w:] Mind Your Own Business! Community Governance in Rural Municipalities, red. G. Peteri, Local Government and Public Service Inititative, Budapest, 2008, s. 79-130. [http://lgi. osi.hu/publications/2008/394/ Mind_Your_Own_Buisness_complete_no_cover.pdf; dostęp: 13.08.2010].

20 P. Matczak, Kiedy dobrobyt zależy od wspótpracy... Dewastacja i odbudowa dóbr wspólnych, [w:] Samorzą pomocniczy jako czynnik pobudzający spoleczeństwo obywatelskie na wsi, red. A. Sakson, P. Węgierkiewicz, Konin, 2010, s. 63.

Tamże, s. 66 .

Tamże, s. 69

Tamże, s. 70 .

${ }^{24}$ K. Bondyra, M. Wojtkowiak, Soltys ma pierwszeństwo, [w:] Samorząd pomocniczy jako czynnik pobudzający społeczeństwo obywatelskie na wsi, red. A. Sakson, P. Węgierkiewicz, Konin 2010, s. 87. 
znawalną osobą w lokalnych społecznościach (ok. (90\% mieszkańców wsi wie, gdzie mieszka sołtys i zna go z imienia i nazwiska), a co więcej cieszącą się dużym autorytetem (70\% badanych jest ogólnie zadowolonych z działalności swojego sołtysa) ${ }^{25}$. Oznacza, to, że pomimo ubogich działań podejmowanych przez sołtysów, dysponują oni dużym potencjałem do animowania życia społecznego wsi. Przekucie możliwości w rzeczywistość wymaga jednak odpowiedniego programu wsparcia. Jednym z jego elementów jest niewątpliwie fundusz sołecki, który zapewnia sołectwom własne środki finansowe na realizację wybranych zadań, i jak pokazuje przykład Opolszczyzny może wydatnie przyczynić się do aktywizowania lokalnej społeczności (każda wioska na Opolszczyźnie korzystająca z tych zasobów ma swój klub ${ }^{26}$ ).

Empirycznych dowodów na możliwości działania lokalnych samorządów dostarczają również liczne bazy danych tzw. „dobrych praktyk”. W Bazie Dobrych Praktyk Związku Gmin Wiejskich RP, Związku Miast Polskich i Związku Powiatów Polskich ${ }^{27}$ odnajdujemy opis gminy wiejskiej Limanowa, która dzięki współpracy, zapoczątkowanej w 2003 roku, z pięcioma innymi gminami na terenie Polski, na przełomie lipca i sierpnia organizuje dwutygodniowe, wahadłowe turnusy kolonijne. Młodzi mieszkańcy gminy Limanowa wyjeżdżają nad morze, a młodzież z gmin nadmorskich w tym samym czasie ma zorganizowany pobyt w gminie Limanowa. Brak pośredników w postaci firm komercyjnych sprawia, że jest to najtańsza zorganizowana forma wypoczynku dla najmłodszych członków gminnej społeczności.

Z kolei gminy Bałtowa i Bodzechowa wspólnie zaangażowały się w projekt, którego celem było stworzenie kompleksowego produktu turystycznego w oparciu o naukowe odkrycia paleontologiczno-geologiczne oraz wykorzystanie sprzyjających warunków krajobrazowo-kulturowych. Rezultatem kooperacji jest nizinny spływ tratwami po rzece Kamiennej oraz pierwszy Polski Park Jurajski. Realizacja tych inicjatyw doprowadziła

25 P. Węgierkiewicz, Potencjał soltysa w tworzeniu spoleczeństwa obywatelskiego na wsi polskiej, [w:] Samorzad pomocniczy jako czynnik pobudzający społeczeństwo obywatelskie na wsi, red. A. Sakson, P. Węgierkiewicz, Konin 2010, s. 113.

P. Szelągowski, Sprawozdanie z dyskusji uczestników konferencji, [w:] Samorząd pomocniczy jako czynnik pobudzający społeczeństwo obywatelskie na wsi, red. A. Sakson, P. Węgierkiewicz, Konin 2010, s. 170.

${ }^{27}$ Dostępne na: http://www.dobrepraktyki.pl/ (18.08.2010); opisane w pracy przykłady z gminy Limanowa, Bajtowa, Bodzechowa, Masłowa, pochodzą z bazy opublikowanej na ww. stronie. 
do utworzenia kilkunastu podmiotów prowadzących działalność gospodarczą i ponad 150 nowych miejsc pracy.

Gmina wiejska Masłowa, jak czytamy w przygotowanym przez nią opisie, w sposób kompleksowy i strategiczny, a zarazem prosty i skuteczny, poprzez Gminny Ośrodek Kultury zarządza lokalnym dziedzictwem kulturowym, przyczyniając się do jego rozpowszechnienia wśród młodzieży i pozostałych mieszkańców gminy. W ramach działań kulturalnych rokrocznie przygotowywany jest Kalendarz Wydarzeń Kulturalnych na 12 miesięcy, które promowane są i współrealizowane przez Gminną Telewizję Internetową i portal informacyjny „Masłów info”, który jednocześnie pełni funkcję archiwum dla wszystkich wyemitowanych programów.

Istotną rolę samorządności w rozwoju obszarów wiejskich podkreślają również liczne projekty w ramach Programu Rozwoju Obszarów Wiejskich. W opracowaniu Wzorowy urzad, czyli jak usprawnić administracje samorzadowa, jak mierzyć jej zadania $i$ wyniki, przygotowanym w ramach projektu „Budowanie potencjału instytucjonalnego administracji lokalnej i regionalnej”, czytamy: „Dobra władza publiczna powoduje wzmocnienie wzajemnego zaufania między obywatelami, wzmocnienie lojalności (regionalnej czy lokalnej) oraz wzmocnienie umiejętności organizacyjnych społeczności. Podstawowe wyzwanie, jakie stoi dzisiaj przed władzą publiczną sprowadza się do tego, aby była ona dla mieszkańców wspólnoty dobrym narzędziem, aby skutecznie wspierała wysiłek społeczeństwa starającego się znaleźć dobre miejsce w lokalnej, regionalnej, narodowej czy europejskiej społeczności" ${ }^{28}$.

\section{Podsumowanie}

Rola samorządu lokalnego w zrównoważonym rozwoju obszarów wiejskich nie powinna zatem być deprecjonowana. Wiele inicjatyw podejmowanych na rzecz ich rozwoju bazuje bowiem na ludzkich, organizacyjnych, informacyjnych, czy finansowych zasobach samorządów lokalnych. Zaprezentowane $\mathrm{w}$ artykule przykłady potwierdzają, że „zaangażowanie oraz aktywna postawa pracowników urzędów gminnych oraz innych lokalnych instytucji pozytywnie wpływa m.in. na rozwój przedsiębiorczości, napływ mieszkańców, powstanie nowych miejsc pracy oraz obiektów

28 Wzorowy urzad, czyli jak usprawnić administracja samorządowa, jak mierzyć jej zadania $i$ wyniki, red. W. Misiąg, Warszawa, 2005, s. 14; [http://www.jst.org.pl/eog/files/ library/lib_Wzorowy.pdf; dostęp: 17.08.2010] 
infrastrukturalnych. Innymi słowy, aktywna postawa władz gmin uruchamia tzw. spiralę rozwoju" ${ }^{29}$. Sprzyja temu zmiana stosunku do samorządu terytorialnego, a zwłaszcza, jak zauważa Andrzej K. Piasecki, w sensie instytucjonalnym przejście od samorządu lokalnego (local government) do zarządzania lokalnego (local governance) ${ }^{30}$. Oznacza to, że samorząd terytorialny staje się odpowiedzialny nie tylko za dostarczanie usług publicznych, ale również za tworzenie przestrzeni umożliwiającej rozwój społeczności lokalnej. „Zarządzanie wyraża się we współpracy różnych podmiotów lokalnej władzy, która przestaje być stopniowo „władzą nad”, a koncentruje się na procesie mobilizacji różnych zasobów w celu osiągnięcia celów jako „władza służąca do" ${ }^{31}$. W kontekście rozwoju obszarów wiejskich oznacza to wyeksponowanie czynników lokalnych, prowadzące do większej integracji grup, które samorząd reprezentuje. Nie jest to oczywiście proces łatwy i szybki, ale w wielu regionach Polski taki sposób myślenia o roli samorządu wydaje się już zapoczątkowany i przynoszący pierwsze satysfakcjonujące rezultaty.

A N NA POKORSKA

J. Smolik, Samorząd gminny i rolnictwo a rozwój obszarów wiejskich, Warszawa 2009, s. 36. A.K. Piasecki, Samorząd terytorialny i wspólnoty lokalne, Warszawa 2009, s. 28.

Tamże, s. 29. 


\section{Abstract}

This article highlights the positive impact that local governments have exerted on the rural development in Poland.

At first, the author presents the basic features of Polish rural areas and examines what rural development means to Polish policy makers. Furthermore, the author concludes that the main ideas which lie at the core of rural development are sustainability, multi functionality and competitiveness. One of the main foundations is also the grassroots approach which involves local community in the development process - the method that is used by many nonprofit or nongovernmental organizations to energize rural areas. Thanks to this strategy their role is still increasing. However, the author gives strong arguments to support the idea that the role of local governments is also crucial in stimulating development, and that this role should be referred to more often. In Poland after ' 89 , thanks to the changes in the law, local governments have the real possibility to run, support or effectively engage in rural development.

Moreover, their workings, as often as not, are the major impulse for positive action taken in rural areas. The author examines this on the basis of the LEADER Programme and Polish Solectwo (the basic level of the Polish local government system).

This article also provides examples of the best practices (from 4 municipalities: Limanowa, Baltowa, Bodzechowa, Maslowa) focusing on the successful initiatives implemented by the local governments. The examples show that, in spite of their weakness, local governments could play an important part in rural development. They make the inhabitants aware of the fact that they are indispensable for everyday life and economic growth to the same extent as NGO's and private enterprises. 